九州大学学術情報リポジトリ

Kyushu University Institutional Repository

\title{
A new form of Annulariopsis from the Carnian Momonoki Formation, Southwest Japan
}

Kim, Jong Heon

Faculty of Science, Kyushu University

Kimura, Tatsuaki

Institute of Natural History

https://doi.org/10.5109/1543640

出版情報：九州大学大学院理学研究院紀要：Series D, Earth and planetary sciences. 27 (2)， pp.101-106, 1992-02-14. Faculty of Science, Kyushu University

バージョン:

権利関係 : 


\title{
A new form of Annulariopsis from the Carnian Momonoki Formation, Southwest Japan
}

\author{
Jong Heon KıM and Tatsuaki KıмURA*
}

\begin{abstract}
A new form of Annulariopsis from the Carnian Momonoki Formation is described, and its comparison with other members of this genus is demonstrated.
\end{abstract}

\section{Foreword}

The generic name Annulariopsis was established for leaf-whorls consisting of small lanceolate and uninerved leaves borne in a terminal position probably through the breaking off of a stem or bud above (ZEILLER, 1902-03; HARRIS, 1961). However, some leaf-whorls, such as Annulariopsis inopinata ZEILler (KIrITchkova, 1969), A. hashimotoi KON'NO (KON'NO, 1972), A. annularioides HUANG et ZHOU (HUANG and ZHou, 1980) and A. bunkeiensis (KoBATAKe) (KIMURA and KIM, B. K., 1988), are attached clearly to the successive stem nodes as leaf-whorls, like those of other sphenophytes. Thus, KimURA and Kim, B. K. (1988) revised the diagnostic character of the genus Annulariopsis on the basis of their newly collected specimens from the Upper Triassic Amisan Formation, Nampo Group, Korea and its equivalents in Korea.

The systematic relation between Lobatannularia KAWASAKI (1927) and Annulariopsis ZEILLER (1902-03) has already been discussed by such authors as HALLE (1927), YABE and KoIWAI (1928), KAWASAKI (1934), Kon'NO and ASAMA (1950), HARRIS (1961) and KIMURA and KIM, B. K. (1988).

This paper deals with the description of Annulariopsis sp. on the basis of newly collected specimens from the Carnian Momonoki Formation. This species is probably new to science but is incompletely known to permit giving a new specific name.

\section{Brief Geology}

Numerous paleobotanical data of the Omine Coal-field in the western part of Yamaguchi Prefecture, western edge of the Honshu Island of Japanese Islands were summarized by OISHI (1940) and KimURA (1980).

The Triassic Miné Group distributed in the Ominé Coal-field rests unconformably on the Permian sediments and is divided into four formations, i. e., Aso, Momonoki, Hirabara and Takiguchi Formations in descending order (TAKAHASI and MiKami, 1975).

The Miné Group has been assigned to the Carnian in age based on its marine benthic invertebrate fossils.

* Institute of Natural History, 24-14-3, Takada, Toshima-ku, Tokyo, 171, Japan.

Manuscript received August 5, 1991 
A

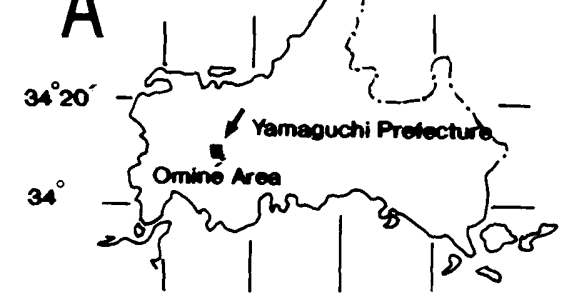

B $131^{\circ} 131^{\circ} 20^{\circ} 131^{\circ} 10^{\circ} 132^{\circ}$
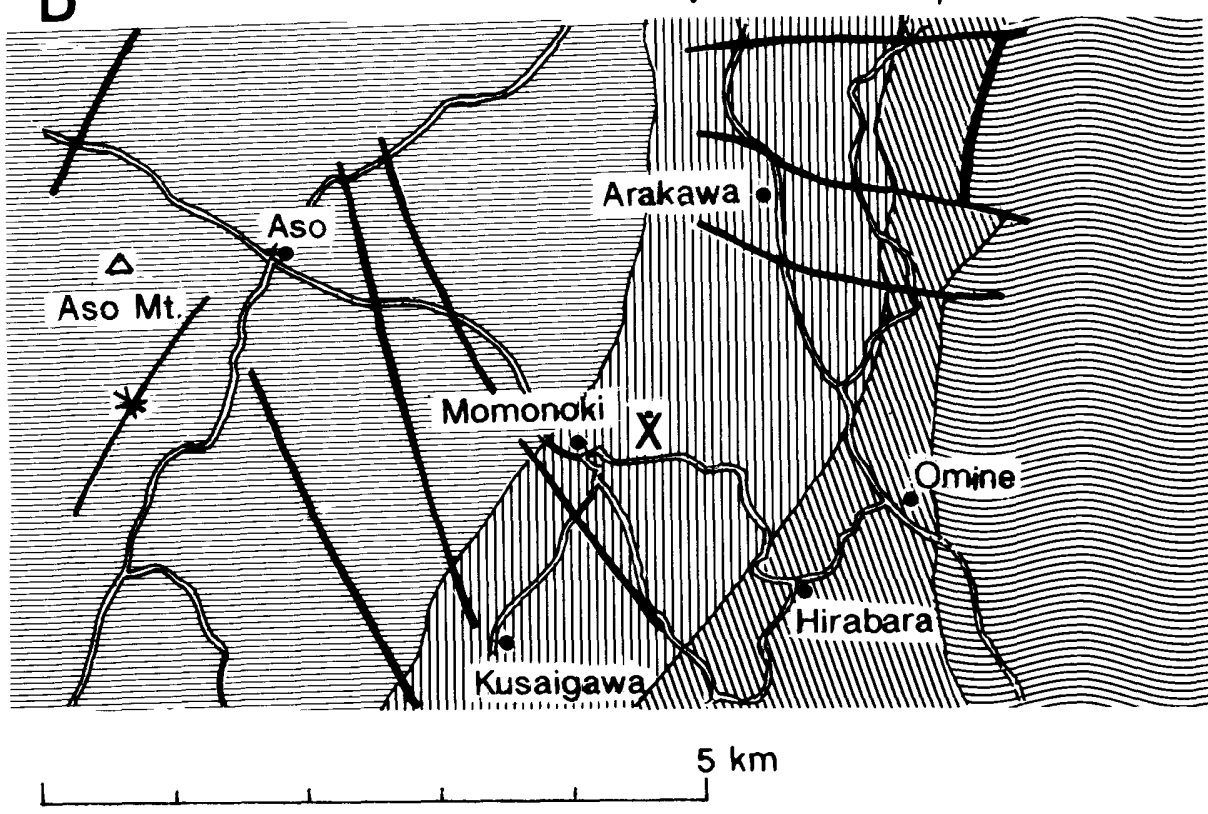

Aso Formation

Momonoki Formation

Hirabara Formation

Permian formation

Fault $*$ Syncline

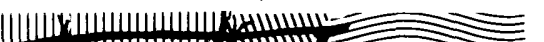




\section{Systematic description}

Order Equisetales

Family Equisetiaceae

Genus Annulariopsis ZeILler em. KImURA and Kim 1988

Type species : Annulariopsis inopinata ZEILLER 1902

Annulariopsis sp.

Figs. 1-2.

1936 Annulariopsis inopinata ZEILler ?: OISHI and TAKAHASI, p. 116, text-fig. 2 (Momonoki).

1940 Annulariopsis inopinata ZEILLER ? : OISHI, 1940, p.185 (Remarks).

Material : GK-S 1-4

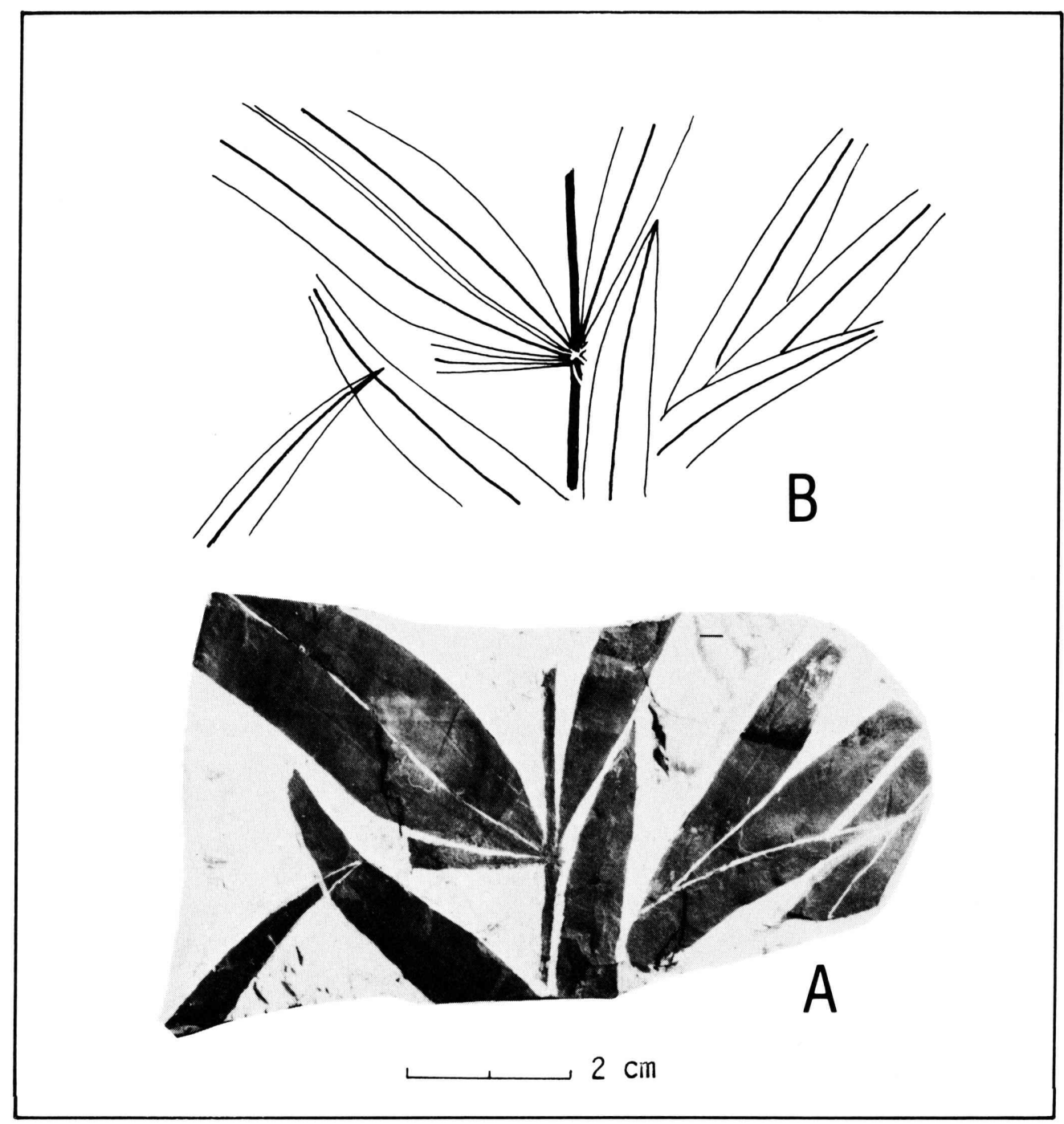

Fig. 2. A : Annulariopsis sp. : A leafy stem with a single leaf-whorl and detached leaves (GK-S 1). B : Drawn from Fig. 2-A. (Figures natural size). 
Description : Articulate plant. Stem slender, $1 \mathrm{~mm}$ wide, surface smooth; internode rather long. Leaf whorl borne at node, not divided into two lobes, spread out in one plane, consisting of 7 or more uninerved leaflets ; leaflets large-sized, lanceolate in shape, with acutely pointed apex, broadest near one third of their length from leaf base, more than $5 \mathrm{~cm}$ long and $9 \mathrm{~mm}$ wide (smaller one up to $5 \mathrm{~mm}$ wide), nearly free at their bases. Midrib distinct, about $0.5 \mathrm{~mm}$ wide, persisting to the tip. Margins entire. Distribution and occurrence: Rare and known from the Miné and Nariwa Groups.

Discussion and comparison: The new material of Annulariopsis sp. is represented by four fragmental specimens. The most distinctive characters of this species are the slender stem with leaf whorl at each node, the seven uninerved and large-sized leaflets and the lanceolate leaflets being free at their base. The present leafy stems differ apparently from other Mesozoic forms by these characteristic states. However, until more information about this leafy stem is sufficiently known, it is provisionally retained in Annulariopsis sp.

Fig. 2 shows a leafy-stem fragment with slender stem bearing a single leaf-whorl. The leaf whorl consists of seven lanceolate leaves of which lower three are represented only by basal part of leaf.

Annulariopsis stems still preserved with lateral leaf whorls in position have rarely been recorded. As far as we know, such stems were described by KIRITCHKOvA (1969) as Annulariopsis inopinata ZEILLER from the middle Keuper beds of Ural, by Kon'No (1972) as $A$. hashimoto $i$ from the Upper Triassic of Sarawak, East Malaysia, by HuANG and ZHOU (1980) as $A$. annularioides and $A$. spp. from the Upper Triassic Yanchang Formation, and by KIMURA and KIM, B. K. (1988) as A. bunkeiensis (KoBATAKe) Kimura et KIM from the Upper Triassic Amisan Formation and its equivalents in Korea.

Among the above mentioned, Annulariopsis hashimotoi and A. bunkeiensis are rather similar in leaf from and number of leaves in a whorl to the present species. Annulariopsis hashimotoi, however, is distinguished from $A$. sp. by its large-sized $(9 \mathrm{~cm}$ long and up to 1.2 to $1.5 \mathrm{~cm}$ wide) and a large number (about 20) of leaves. $A$. bunkeiensis is distinguished from the present species by its spatulate leaves with emarginate apex. The other two species are also distinguishable from the present one by their form, size and number of leaves.

Besides the above, the following leaves of Neocalamites and Annulariopsis are similar in form, size and number of leaves to the present specimens, but are distinguished from the other by the respective reason as briefly mentioned below :

Neocalamites carcinoides HARRIS : SzE, 1956 ; SzE et al., 1963, Upper Triassic Yanchang Formation : Leaf whorl divided into two lobes, leaves size up to $12 \mathrm{~cm}$ long and 5 to $6 \mathrm{~mm}$ wide.

Neocalamites minensis KON'NO et NAITO : Kon'NO and NAITO, 1960, Carnian Momonoki Formation: Leaf whorl consisting of 8 to 12 leaves and divided into two lobes.

Annulariopsis ? sp. (= Neocalamites annularioides, according to SzE, 1956) : SzE, 1956 ; SzE et al., 1963, Upper Triassic of Junggar Basin : Leaf whorl consisting of 8 to 12 linear-lanceolate leaves.

Annulariopsis ? sinensis (NGO) LEF : SzE et al., 1963, Upper Triassic Xiaoping 
Formation : Leaf apex rounded.

Annulariopsis inopinata ZEILLER : ZEILLER, 1902-3, Upper Triassic of North Viet

Nam : Leaf whorl consisting of 16 to 24 lanceolate or spatulate leaves with obtusely pointed apex.

OISHI (1930, '32, '40) and OISHI and TAKAHASI (1936) described three leaf whorls from the Nariwa Group and a single broken leaf whorl from the Momonoki Formation as Annulariopsis inopinata? respectively. Of them the last one is highly referable to the present leafy stems of Annulariopsis sp.

\section{Acknowledgments}

The junior author (KIM) thanks Professor Dr. Atsuo AiHARA of the Department of Earth and Planetary Sciences, Faculty of Science, Kyushu University for his advice. We also thank Mr. Gentaro NAITo and Mr. Fumio TAKAHASHI of the Miné City Museum of History and Folk-Custom who cooperated with us in collecting the present specimens.

This study was supported in part by the Professor Tatsuro MATsumoto scholarship fund given to KIM.

\section{References}

DuAn, S. Y. and CHEN, Y. (1984) : On plant megafossils from the Late Triassic sediments of the Eastern part of Sichuan Basin, China. Palaeobot., 32, (3), 203-210.

Halle, T. G. (1927) : Palaeozoic plants from Central Shanxi. Palaeont. Sinica, [1], 2, (1), 1-317, pls. 1-64.

HARRIS, T. M. (1961) : The Yorkshire Jurassic flora 1. 1-212, Bull. Brit. Mus. (Nat. Hist.).

HuANG, Z. G. and ZHOU, H. Q. (1980) : Fossil plants. In Chinese Acad. Geol. Sci. (ed.) : Mesozoic stratigraphy and Palaeontology from the basin of Shaanxi, Gansu and Ningxia (I). 43-114, Geol. Publ. House, Beijing (in Chinese).

KAWASAKI, S. (1927) : The flora of the Heian System. Part 1. Equisetales and Sphenophyllales. Bull. Geol. Surv. Chosen (Korea), 6, (1), 1-30, pls. 1-16.

— (1934) : The flora of the Heian System. Part 2. Text. Ibid., 6, (4) , 47-311, pls. 105-110.

KIMURA, T. (1980) : The present status of the Mesozoic land floras of Japan. Prof. Saburo Mem. Vol., 379-413.

KIMURA, T. and KIM, B. K., 1988 : New taxa in the Late Triassic Daedong flora, South Korea. Part 1. Trans. Proc. Palaeont. Soc. Japan, [N. S. ], (152), 603-624.

Kimura, T., Naito, G. and Ohana, T. (1983) : Baiera cf. furcata (Lindley and HutTon) Braun from the Carnic Momonoki Formation, Japan. Bull. Nat. Sci. Mus., Tokyo, [C], 9, (3), 91-114.

KIRITCHKOVA, A. I. (1969) : Data to the research on the Early Mesozoic Floras of Eastern Ural. Bull. VNIGRI, 268, (4), 270-315, pls. 1-17 (in Russian).

Kon'NO, E. (1972) : Some Late Triassic plants from the Southwestern border of Sarawak, East Malaysia. Geol. Palaeont. SE-Asia, 10, 125-178, pls. 24-32. Univ. Tokyo Press.

KON'NO, E. and ASAMA, K. (1950) : On the genus Lobatannularia Kawasaki, 1927 from Permian beds in South Manchuria and Shanxi, China. Short papers IGPS, Tohoku Univ., (I), 18-31, pl. 4.

Kon'NO, E. and NAITO, G. (1960) : A new Neocalamites from the Carnic formation in Japan with brief notes on Neocalamites and Lobatannularia in Asia. Trans. Proc. Palaeont. Soc. 
Japan, [N. S. ], (40), 339-351, pls. 40-41.

OISHI, S. (1930) : Notes on some fossil plants from the Upper Triassic beds of Nariwa, Prov. Bitchu, Japan. Jap. Jour. Geol. Geogr., 7, (2), 49-58, pl. 7.

(1932) : The Rhaetic plants from the Nariwa District, Prov. Bitchu (Okayama Prefecture), Japan. Jour. Fac. Sci., Hokkaido Imp. Univ., [4], 1, (3-4), 257-380, 19-53.

(1940) : The Mesozoic floras of Japan. Ibid., 5, (2-4), 123-480, pls. 1-48.

OISHI, S. and TAKAHASI, E. (1936) : The Rhaetic plants from Prov. Nagato. A supplement. Ibid., 3, (2), 113-133, pl. 10.

SzE, H. C. (1956) : Older Mesozoic plants from the Yanchang Formation, Northern Shanxi. Palaeont. Sinica, [A], 5 , (139), 1-217, pls. 1-56. (in Chinese and English).

SZE, H. C., Li . X. X., Li , P. J., Zhou, Z. Y., Wu, S. Q., Ye, M. N. and Shen, G. L. (1963) : Mesozoic plants from China. Fossil plants of China. 2.1-429, pls. 1-118. Sci. Press, Beijing (in Chinese).

TAKAHASI, E. and MiKami, T. (1975) : The Triassic System in Yamaguchi Prefecture. In Geology of Yamaguchi Prefecture., 93-108, Yamaguchi Museum (in Japanese).

YABE, H. and KoIWAI, K. (1928) : Remarks on the genera Annulariopsis, Lobatannularia and Annularites. Proc. Imp. Acad., 4, (9), 537-540.

ZEILlER, R. (1902-03) : Flore fossile des gites de charbon du Tonkin (Etudes de gîtes minéraux de la. France). 1-328, pls. 1-56, Paris. 